\title{
Effect of Competition and Regulation on MFIs Outcomes in India
}

\author{
Debapratim Purkayastha1, Trilochan Tripathy ${ }^{2 *}$, Biswajit Das ${ }^{3}$ \\ ${ }^{1}$ IBS Hyderabad, ICFAI Foundation for Higher Education, Hyderabad, India \\ ${ }^{2}$ XLRI-Xavier School of Management, Jamshedpur, India \\ ${ }^{3}$ KIIT School of Management, KIIT University, Bhubaneswar, India \\ Email: debapratim@icmrindia.org, *trilochan@xlri.ac.in, biswajit@ksom.ac.in
}

How to cite this paper: Purkayastha, D., Tripathy, T. and Das, B. (2018) Effect of Competition and Regulation on MFIs Outcomes in India. Theoretical Economics Letters, 8, 1161-1178.

https://doi.org/10.4236/tel.2018.85077

Received: February 1, 2018

Accepted: April 17, 2018

Published: April 20, 2018

Copyright (c) 2018 by authors and Scientific Research Publishing Inc. This work is licensed under the Creative Commons Attribution International License (CC BY 4.0).

http://creativecommons.org/licenses/by/4.0/

(c) (i) Open Access

\begin{abstract}
The purpose of this paper is to examine the effect of competition and regulation on Microfinance Institutions (MFIs) outcomes in India. Using data for 60 MFIs from the MIX Market database for a period of five years from 2008-09 to 2012-13, panel models are estimated for the empirical examinations. In the modeling framework, constructed Lerner's Index as competition proxy and regulate dummy as regulatory intervention proxy are introduced as interest variables along with the MFI specific and Macro specific control variables to examine their effect on MFIs outcomes. The study reveals that competition strengthens the outreach, promotes operating efficiency, deteriorates the loan portfolio quality and adversely affects the MFIs profitability. While the regulatory intervention creates some accommodative space for the MFI borrowers, improves MFIs efficiency partially and dampens loan repayments and portfolio quality and profitability via "roe" in India. Our results have also implications on MFIs, fund provider, regulator, government and policy research practitioners. This study contributes towards filling gap in the literature by extending the analysis of the effect of competition and regulation on MFI outcomes to a cross-section of states in India in a panel data framework.
\end{abstract}

\section{Keywords}

Competition, Regulation, Microfinance, Efficiency, Outreach, Performance

\section{Introduction}

The developing economies have witnessed a rapid proliferation of microfinance institutions (MFIs). The emergences of MFIs in these economies are due to subsidized funding from government, non-governmental organizations, commercial 
banks and specialized financial institutions [1]. Further proliferation of commercial orientation and "for profit" MFIs in the marketplace have rapidly increased competition among MFIs in several countries [2]. In a competitive setting, degree of competition has a bearing on the performance, efficiency, outreach, profitability [3] indebtedness [4], service quality [2], product innovation and development and diversity [5]. However, to ensure the healthy competition in the microfinance industry, governments in many economies have put in place strict regulations. Regulatory intervention of Andhra Pradesh Government in 2010 followed by Reserve Bank of India regulation for entire India has largely impacted the MFIs in the country. However, there are few systematic empirical evidences for such a claim being made. As the effect of competition and regulation on MFI outcomes are highly understudied in India, and this being such an important area from the strategic perspective, this study makes an attempt to fill this gap in the existing stock of microfinance literature.

The specific objectives of this study are 1) to examine the effect of competition on MFIs outreach, loan repayment, efficiency and financial performance in the Indian microfinance Industry and 2) to examine the effect of regulatory intervention on MFIs outreach, loan repayment, efficiency and financial performance in the Indian microfinance industry. The outcome of this study would influence the diverse stakeholders of microfinance including MFIs, beneficiaries, donor agencies, liquidity providers, market regulator and both state and central governments in India. The rest of the paper is organized under four sections. Section 2 identifies the gap by reviewing the literature relating to the effect of competition and regulation on MFI outcomes and thereby develops the hypotheses for the study. Data and methodology used in this study is presented in section 3. The preliminary and empirical results are captured in the section 4 . Section 5 provides the discussion of the findings and the reasons associated thereof. Conclusion, limitations, contributions and future scope of the study are narrated in the last section.

\section{Hypotheses Development}

\subsection{Competition and MFI Outcomes}

The efficient structure hypothesis posits a reverse causality between competition and efficiency [6]. Earle and Estrin [7] explore the inverse relationship between competition and firm performance. Navajas, et al. [8] report that outcome of competition is ambiguous since competition lead to innovation and in turn expanding outreach. However, researchers have also found that competition reduces the ability of lenders to cross-subsidize less profitable smaller loans. Vogelgesang's [4] study reveals that competition prompts multiple borrowings and higher levels of borrower indebtedness. McIntosh and Wydick [9] reveal that competition increase information asymmetry which deteriorates the loan portfolio quality and in turn loan delinquencies in the multi-lender market [10]. Berger et al. [11] find that large firms' competitive pressures have more deleterious 
effects on the performance of their small, single-market rivals in a later period. The wide variations in operating costs across MFIs are observed, often within the same geographical region, which is attributed to competition [12] [13]. Competition also affects the financial stability of the financial institutions [14]. On the other hand, Kai [15] suggests that competition does not affect the financial self-sufficiency but negatively affect wider outreach where such a negative impact declines with increase in MFIs experience. Competition among lenders for external funds can lead to higher aggregate poverty reduction and food security [1] [16]. The competition among MFIs may influence the micro credit market dynamics by lowering the interest rate and in turn improve the service access to poor clients [17]. Assefa, et al. [3] suggests that intense competition is overall, negatively associated with the MFIs performances.

Though literature on the effect of competition on MFI outcomes are quite exhaustive, still it has remained inconclusive, which varies across the market. Keeping the competition and MFI outcomes literature in mind, following four set of hypotheses are tested in this study:

H1.1: That, competition adversely affects MFIs outreach.

H1.1.1 Competition adversely affects MFIs active borrowers base.

H1.1.2 Competition adversely affects MFIs loan size.

H1.2: That, Competition adversely affects MFIs loan repayment.

H1.2.1 Competition adversely affects MFIs short term portfolio quality.

H1.2.2 Competition adversely affects MFIs long term portfolio quality.

H1:3: That, Competition adversely affects MFI's Efficiency.

H1.3.1 Competition adversely affects MFIs operating efficiency.

H1.3.2 Competition adversely affects MFIs average cost per borrowings.

H1:4: That, competition adversely affects MFI's Profitability.

H1.4.1 Competition adversely affects MFIs operating self efficiency.

H1.4.2 Competition adversely affects MFIs operating profit.

H1.4.3 Competition adversely affects MFIs return on asset.

H1.4.4 Competition negatively affects MFIs return on equity.

\subsection{Regulation and MFI Outcomes}

Effect of regulation on firm performance is amply studied in strategic finance literature. However, the effect of regulation on MFIs outcomes is highly understudied in the strategic finance literature. Regulations also influence the other contextual factors in the macro-environment of a firm, particularly smaller firms, and such effect may be more important for organizations such as MFIs, many of which operate on a small scale [18]. Cull et al. [19] shows empirical evidence that demonstrates that supervision is negatively associated with profitability but with larger average loan sizes and lesser lending to women. Christen and Rosenberg [20] report that compliance with prudential regulations could cost a MFI 5\% of assets in the first year and $1 \%$ or more thereafter. Ndambu [21] claims that the regulatory status neither increases the operational self-sufficiency 
nor does the deposit intermediation of the MFIs. However, after controlling for the regulatory capacity, countries having a high official supervisory power have more sustainable MFIs. It is only after integrating the official supervisory power in the model, the deposit intermediation coefficient becomes significant and positively associated with the operational self-sufficiency. Wanjiru's [22] study concludes that the regulations lead to increase in the value of loans outstanding, total assets, the profit and shareholders' equity of Deposit Taking Microfinance Institutions (DTMIs). However, the DTMIs encounter challenges such as high costs of transformation, high costs of operation, licensing costs and stiff competition from other financial institutions. Yu et al. [23] demonstrate that more stringent prudential regulation increases MFI profitability and decreases in outreach. Hartarska and Nadolnyak [24] affirm that regulatory intervention neither directly affects operational self-sustainability nor outreach of MFIs. However, it is the less leveraged MFIs who are having better financial sustainability. Further, Assefa, et al. [3] suggest that the adverse effect of competition can be overcome by ensuring lending standards, enhancing information sharing and promoting efficiency.

Review of literature ascribes the importance of regulation in the context of MFIs in general and India in particular. Keeping the importance of regulation on MFI outcome literature in mind, following four set of hypotheses are tested in this study:

H2.1: That, regulation adversely affects MFIs outreach.

H2.1.1 regulation adversely affects MFIs active borrowers' base.

H2.1.2 regulation adversely affects MFIs loan size.

H2.2: That, regulation adversely affects MFIs loan repayment.

H2.2.1 regulation adversely affects MFIs short term portfolio quality.

H2.2.2 regulation adversely affects MFIs long term portfolio quality.

H2:3: That, regulation adversely affects MFI's Efficiency.

H2.3.1 regulation adversely affects MFIs operating efficiency.

H2.3.2 regulation adversely affects MFIs average cost per borrowings.

H2:4: That, regulation adversely affects MFI's Profitability.

H2.4.1 regulation adversely affects MFIs operating self-efficiency.

H2.4.2 regulation adversely affects MFIs operating profit.

H2.4.3 regulation adversely affects MFIs return on asset.

H1.4.4 Competition negatively affects MFIs return on equity.

\section{Data and Methodology}

\subsection{Nature and Sources of Data}

Empirical examination is based on the secondary data which have been obtained from diverse sources. However, the MIX market database is the major source of data. The competition and regulation are two interest variable in our study and these variables are constructed using the annual MIX market data. All other MFI specific control variables are also obtained from the MIX market data. However, 
the macro specific variables such as real yield, per capita gross state domestic product and credit deposit ratio have been obtained from the respective states statistical abstracts. Further, and CRISIL financial inclusion index is obtained from the CRISIL annual reports. The explanatory variables are of annual frequencies related to MFIs and these are obtained from MIX data base. The period of the study ranges from 2008-09 to 2012-13. Initially we tried to search sample information for 300 firms but due to non-availability/missing data in some parameters and we finally carried out the examination for the 60 MFIs representing from six different regions and 18 states of India.

\subsection{Constructs and Variables}

Explanatory Variables: Empirical examination is conducted for two interest variables i.e. competition and regulation. The definition and variable construction methodology is presented hereunder:

Measurement of Competition: The Learner Index (LI) is employed as a proxy to measure the extent of competition across the firms within the respective industries. The formula used for computing competition is: $\mathrm{LI}=(\mathrm{P}-\mathrm{MC}) / \mathrm{P}$. Where "P" is the average revenue and MC is marginal cost. Following the estimation procedures of Guevara and Maudos [25], output price (P) is computed as the ratio of operating income to total asset. The marginal cost is derived from the following estimated the translog cost function:

$$
\begin{aligned}
\operatorname{LnC}_{i, t}= & \alpha_{0}+\alpha_{1} \ln y_{i, t}+\frac{1}{2} \alpha_{2}\left(\ln y_{i, t}\right)^{2}+\sum_{j=1}^{2} \beta_{j} \ln w_{j, i, t}+\sum_{j=1}^{2} \beta_{j}\left(\ln w_{j, i, t}\right)^{2} \\
& +\sum_{j=1}^{2} \gamma_{j} \ln y_{i, t} \ln w_{i, j, t}+\sum_{j<k} \sum \gamma_{j, k} \ln w_{i, j, t} \ln w_{i, k, t}+\delta_{1} \text { Trend } \\
& +\frac{1}{2} \delta_{2} \text { Trend }^{2}+\delta_{3} y_{i, t} \text { TimeTrend }+\sum_{j=1}^{2} \eta_{j} \ln w_{i, j, t} \text { Trend }+\varepsilon_{i, t}
\end{aligned}
$$

where $C_{i, t}$ is the total cost of the firm " $\vec{i}$ " at year " $t$ ". The explanatory variable

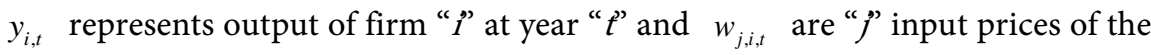
firm " $i$ " at year " $l$ ". In estimating input prices of the firms, we have assumed two factor input prices such as labour (w1) and capital (w2). The cost of labor is computed as a ratio of personal expenses to total number of employees and the cost of capital is computed as the ratio of operating expenses without personnel expenses to net fixed asset. Following the Hermes, et al. [26] translog cost function specification, we have estimated the cost frontier including a time trend, where total cost is sum of the operating and financial costs of the firm " $i$ " at year " $t$ ". The rationale of inclusion of time trend in cost frontier estimation is to capture the effect of technological change and firm specific fixed effect to deal with the unobserved firm heterogeneity in the industry and associated difference in cost.

The marginal cost (MC) of the firm " $"$ " at year " $t$ " is derived by taking the derivative of the total cost function with respect to $\ln y_{i, t}$. The equation for MC is given hereunder: 


$$
M C_{i, t}=\left(C_{i, t} / y_{i, t}\right)\left[\alpha_{1}+\alpha_{2} \ln y_{i, t}+\sum_{j=1}^{2} \gamma_{j} \ln w_{j, i, t}+\delta_{3} \text { Trend }\right]
$$

MC is estimated from the observed variables $\left(C_{i, t}\right.$-total cost, $y_{i, t}$-total output and input prices- $\left.w_{j, i, t}\right)$ and estimated translog cost function coefficients $\left(\alpha_{1}\right.$, $\alpha_{2}, \gamma_{j}$ and $\delta_{3}$ ).

Measurement of Regulation: we have engaged a dummy variable to measure the state intervention to regulate MFIs. The regulation dummy is a time dummy before and after the Andhra Pradesh Government's order to regulate the MFIs in the state followed by Reserve Bank of India MFI regulation Act. Such regulation came into force from the year 2010. Keeping this in mind, we have constructed a dummy variable which captures the state of post regulation period assigning a value " 1 " and pre regulation period assigning a value " 0 ". It has been reported in the media that such a regulation has impacted MFIs across India. Further this regulation panic wave is seen to have reflected in MFI stock prices in India, where many MFI stock prices plummeted. Thus, to capture the effect of such a regulatory shock, we have constructed the regulation dummy for all the MFIs across the time domain.

Explained Variables: Four sets of explained variables are used in the empirical examinations which are measured through different MFI outcome proxies. These variables are explained hereunder:

Outreach: It is a widely used measure of performance of the MFI for the depth and width of financial inclusion. Literature suggests seven different measures for outreach of an MFI [27] [28]. However, based on the MIX market data, two proxies are engaged for the outreach measurement i.e. number of active borrowers (nab) and average loan balance per borrower (albpb). The first indicator measures the breadth of outreach of MFI while the second measure is proxy for depth in outreach [3] [26] [29] [30] [31]. In this study, "nab" refers to those borrowers who are part of the loan book of the MFIs. While the loan size proxy is captured by "albpb".

Loan Repayment: The loan portfolio quality and how well the MFI is collecting its loans are also other indicators of MFI performance. A MFI lender's ability to collect loans is critical for its success and if delinquency is not kept to very low levels, it can quickly spin out of control. Furthermore, loan collection has proved to be a strong proxy for general management competence. Following Assefa, et al. [3], we include portfolio at risk greater than 30 days (PAR30) and 90 days (PAR90) as MFI loan repayment performance in this study. These measures help us to assess loan repayment performance of clients and portfolio quality of MFIs.

Efficiency: Lending institutions overall efficiency is generally measured by operating expenses ratio (OER). Following the literature [3], operating efficiency ratio (oer) and cost per borrower (cpb) have been used as proxies for efficiency measure of MFIs. A given MFI is usually regarded as having become more efficient when the "oer" and "cpb" get lower [3].

Profitability: Following the existing literature [3], four proxies such as opera- 
tional self-sufficiency (oss), operating profit margin (opm), return on assets (roa) and return on equity (roe) are chosen to measure MFIs profitability. Before designing the econometric models, it is worth theorizing the direction of signs associated with the dependent and independent variables, which are presented, in nutshell, in Table 1.

\section{Econometric Models Used}

A variant of Hartarska \& Nadolnyak [24] model is calibrated here to empirically examine the effect of competition and regulation on MFI outcomes in the presence of MFI industry-specific and macroeconomic variables. Our estimation equation takes the following form:

$$
y_{i, j, t}=\alpha+\beta L I_{i, j, t}+\phi D R+\gamma x_{i, j, t}+\lambda z_{j, t}+T+\varepsilon_{i, t}
$$

where

$y_{i, j, t}$ is a measure of performance of MFI " $i$ " located in state " $j$ " and at time period " $t$ ",

$L I_{i, j, t}$ is the Lerner Index which measures competition faced by MFI i, located in state " $j$ " at time period " $e$ ",

Table 1. Theoretical and estimated signs associated with the effect of competition and regulation on MFIs outcomes.

\begin{tabular}{|c|c|c|c|c|}
\hline & Parameter & Definitions used & $\begin{array}{c}\text { Sign } \\
\text { associated } \\
\text { with the LI }\end{array}$ & $\begin{array}{l}\text { Sign associated } \\
\text { with the Effect of } \\
\text { Regulation }\end{array}$ \\
\hline \multirow{2}{*}{ 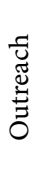 } & $\begin{array}{l}\text { No. of Active } \\
\text { Borrowers (nab) }\end{array}$ & Number of active borrowers & $+/-[-]$ & $-1+[+]$ \\
\hline & Loan size (albpb) & $\begin{array}{l}\text { Ratio of total loan balance to total } \\
\text { no. of active borrowers }\end{array}$ & $+/-[-]$ & $-1+[-]$ \\
\hline \multirow{2}{*}{ 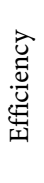 } & $\begin{array}{l}\text { Cost per Borrower } \\
(\mathrm{cpb})\end{array}$ & $\begin{array}{l}\text { Average cost incurred by a MFI to } \\
\text { retain an active borrower }\end{array}$ & $-[-]$ & $+/-[-]$ \\
\hline & $\begin{array}{l}\text { Operating Expenses } \\
\text { Ratio (oer) }\end{array}$ & $\begin{array}{l}\text { Ratio between operating expenses } \\
\text { and average gross loan portfolio }\end{array}$ & $-[-]$ & $\begin{array}{l}+1- \\
{[-]}\end{array}$ \\
\hline \multirow{2}{*}{ 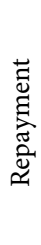 } & $\begin{array}{l}\text { Portfolio at Risk under } \\
30 \text { days (PAR 30) }\end{array}$ & $\begin{array}{l}\text { Portion of loan portfolio that is } \\
\text { overdue and at risk of not being } \\
\text { repaid under } 30 \text { days }\end{array}$ & $-[-]$ & $+/-$ [inconclusive $]$ \\
\hline & $\begin{array}{l}\text { Portfolio at Risk under } \\
90 \text { days (PAR 90) }\end{array}$ & $\begin{array}{l}\text { Portion of loan portfolio that is } \\
\text { overdue and at risk of not being } \\
\text { repaid under } 90 \text { days }\end{array}$ & $\begin{array}{l}- \\
\text { [inconclu- } \\
\text { sive }]\end{array}$ & $+/-[-]$ \\
\hline \multirow{4}{*}{ 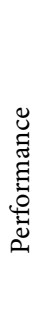 } & $\begin{array}{l}\text { Operating Self } \\
\text { Sufficiency (oss) }\end{array}$ & $\begin{array}{c}\text { Ratio of Operating Cost to Loan } \\
\text { Size }\end{array}$ & $-/+[+]$ & 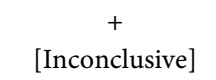 \\
\hline & Profit Margin (pm) & $\begin{array}{c}\text { Ratio of Net Operating Income to } \\
\text { Financial Revenue }\end{array}$ & $-1+[+]$ & $\begin{array}{c}+ \\
\text { [Inconclusive] }\end{array}$ \\
\hline & Return on Asset (roa) & Net operating income/assets & $-/+[+]$ & $\begin{array}{c}+ \\
\text { [Inconclusive] }\end{array}$ \\
\hline & Return on Equity (roe) & Net operating income/total equity & $-1+[+]$ & $+[-]$ \\
\hline
\end{tabular}

Note: Figures in square brackets indicates the estimated signs obtained from multivariate signs otherwise theoretical signs. 
$\mathrm{DR}$ is a regulation dummy, where 1 is regulated, 0 otherwise.

$x_{i, j, t}$ is a vector of other MFI characterized explanatory variables attached to MFI " $\ddot{i}$ " located in state " $\vec{j}$ " and at time period " $\vec{c}$ ",

$z_{j, t}$ is a vector of macro characterized state level variables linked with the MFIs located in state " $j$ " and at time period " $t$ ", and

$\mathrm{T}$ represents the time trend.

It is a panel data equation, where we apply a Hausman test to compare between fixed and random effects estimates. Trend is also included in the regression since it would be unreasonable to assume the relation between competition, regulation and MFIs performance is constant over time. We have engaged the generalized linear model (GLM) as a model estimation strategy, which allows for response variables that have error distribution models other than a normal distribution.

\section{Results and Discussions}

\subsection{Preliminary Findings}

The descriptive statistics for the two explanatory variables (competition and regulation) and all dependent variables (outreach, efficiency, repayment and performance) are presented in Table 2.

The results suggest that the mean value of the Lerner's Index (LI) is 0.392, which suggests that the competition among MFIs is high. The descriptive statistics also suggest that about $62 \%$ of MFIs are regulated and $69 \%$ of MFIs under

Table 2. Descriptive statistics associated with the main variables under the study.

\begin{tabular}{|c|c|c|c|c|c|c|c|}
\hline $\begin{array}{c}\text { Broad } \\
\text { Variables }\end{array}$ & $\begin{array}{c}\text { Specific } \\
\text { Variables }\end{array}$ & Minimum & Maximum & Mean & Std. Deviation & Skewness & Kurtosis \\
\hline \multicolumn{8}{|c|}{ Interest explanatory variables } \\
\hline Competition & LI & 0.050 & 1.000 & 0.392 & 0.171 & -2.253 & 5.602 \\
\hline \multirow[t]{2}{*}{ Regulation } & Dregulate & 0.000 & 1.000 & 0.623 & 0.485 & -0.512 & -1.750 \\
\hline & \multicolumn{7}{|c|}{ Explained Variables } \\
\hline \multirow{2}{*}{ Outreach } & nab & 382 & 4188655 & 181852 & 517662 & 5.19 & 29.14 \\
\hline & albpb & 0.00 & 426.00 & 106.42 & 53.81 & 1.64 & 7.85 \\
\hline \multirow{2}{*}{ Efficiency } & $\mathrm{cpb}$ & 0.05 & 381.13 & 18.97 & 24.75 & 10.85 & 154.07 \\
\hline & oer & 0.01 & 0.69 & 0.13 & 0.08 & 2.28 & 9.87 \\
\hline \multirow{2}{*}{ Repayment } & par30 & 0.00 & 1.00 & 0.06 & 0.17 & 4.13 & 16.83 \\
\hline & par90 & 0.00 & 0.98 & 0.05 & 0.17 & 4.44 & 19.35 \\
\hline \multirow{4}{*}{ Performance } & oss & -0.12 & 2.21 & 1.09 & 0.29 & -0.70 & 4.96 \\
\hline & $\mathrm{pm}$ & -23.08 & 2.46 & -0.09 & 1.69 & -11.16 & 136.68 \\
\hline & roa & -0.19 & 2.79 & 0.18 & 0.30 & 3.27 & 18.62 \\
\hline & roe & -1.24 & 1.47 & 0.22 & 0.28 & 0.72 & 6.35 \\
\hline \multicolumn{2}{|c|}{ Valid N } & 300.00 & 300.00 & 300.00 & 300.00 & 300.00 & 300.00 \\
\hline
\end{tabular}


investigation are having medium scale of operation. The MFI operation is largely concentrated in the southern states of India though not reported here. The mean value of MFIs total asset is about Rs.3.1 crores, which is highly dispersed among MFIs under investigation. Further, the skewness and kurtosis statistics suggests that the total asset distribution is highly asymmetric having fat tails in its distribution structure. Further, he high standard deviation attached to "nab" indicates that MFI active borrowers' base is quite diversified in India. However, the highest geographic concentration is observed to be in south and lowest in the north eastern regions of India (results not reported here). The skewness and kurtosis result also suggest that "nab" distribution across MFIs are asymmetric and a fewer number of MFIs are having relatively larger "nab" compared to many others. The average "albpb" suggests that Indian MFIs supports small size loans. The mean and standard deviation of two operational efficiency constructs i.e. "cpb" and "oer" are observed to be 18.97 and 0.1342 and 24.75 and 0.08213 respectively, which suggest that MFIs are operating efficiently with low operating risk. While the mean and standard deviation of two repayment proxies i.e. "par30" and "par90" for the MFIs under investigation are observed to be 0.614, 0.174 and $0.507,0.166$ respectively, which indicate that MFIs loan portfolios are under lower risks. The mean value of four MFI performance measures i.e. "oss", "pm", "roa" and "roe" are found to be highly positive, which indicates that MFIs are performing well in profitability fronts.

Keeping the academic brevity in mind, we have not presented the results associated with the correlation analysis of the explanatory variables. However the results suggest that explanatory variables chosen in this study are weakly correlated with each other except the Crisil Financial Inclusion Index (CRIX), which has been removed from the further empirical analysis.

\subsection{Main Findings and Discussions}

This section is organized under two sub-sections i.e. univariate analysis and multivariate analysis. The first subsection delineates the estimates of the univariate panel model, where the contemporaneous effect of the competition on MFI outcomes is examined. The assumption on univariate model specification is no longer valid and the performance of MFIs is only influenced by competition but also by the host of factors. However, the univariate analysis gives an indication of the robustness of the effect of competition to the inclusion of additional explanatory variables. The estimation is performed in a panel setting with LI as MFI specific variable and the results are reported in Table 3. In the second sub-section, we present the estimates of the multivariate panel regression models, where the effect of competition and regulations are examined in the presence of MFI and macroeconomic specific factors as controls. A model selection examination is extensively undertaken to arrive at the best linear unbiased estimator in a multivariate panel settings.

Univariate Results Analysis: An attempt is made here to find out how LI as a 
Table 3. Univariate results on effect of competition on MFI outcomes.

\begin{tabular}{|c|c|c|c|c|c|c|c|c|c|c|}
\hline \multirow[b]{2}{*}{ Descriptions } & \multicolumn{2}{|c|}{ Outreach } & \multicolumn{2}{|c|}{ Repayment } & \multicolumn{2}{|c|}{ Efficiency } & \multicolumn{4}{|c|}{ Profitability } \\
\hline & $\mathrm{Nab}$ & Albpb & par 30 & par 90 & Oer & $\mathrm{Cpb}$ & oss & $\mathrm{pm}$ & roa & roe \\
\hline \multirow{2}{*}{ Constant } & $11.157^{\star * *}$ & $7.124^{\star * *}$ & $0.151^{\star * *}$ & $0.113^{* *}$ & $0.274^{* * *}$ & $2.235^{\star \star \star}$ & $1.022^{\star \star \star}$ & 0.281 & 0.003 & 0.003457 \\
\hline & (36.12) & $(28.16)$ & $(2.67)$ & $(2.13)$ & (10.44) & $(38.24)$ & $(10.41)$ & $(0.55)$ & $(0.26)$ & $(0.37)$ \\
\hline \multirow{2}{*}{ LI } & $-0.5742^{\star *}$ & $-0.615^{\star \star}$ & $-0.301^{* *}$ & $-0.098^{* *}$ & $0.157^{\star * *}$ & $0.105^{\star}$ & $0.373^{\star * *}$ & $0.417^{\star * *}$ & $0.019^{*}$ & $0.021^{\star *}$ \\
\hline & $(-2.08)$ & $(-2.24)$ & $(-2.02)$ & $(-1.99)$ & $(5.61)$ & $(1.78)$ & $(2.67)$ & $(2.97)$ & $(1.93)$ & $(2.03)$ \\
\hline R Square & 0.0143 & 0.0878 & 0.0087 & 0.0048 & 0.0958 & 0.0105 & 0.015 & 0.018 & 0.0083 & 0.0035 \\
\hline HM Statistic & 37.75 & 6.901 & 2.15 & 1.66 & 6.34 & 0.02 & 0.47 & 0.21 & 3.47 & $(0.37)$ \\
\hline $\mathrm{p}$-value & {$[0.001]$} & {$[0.0086]$} & {$[0.142]$} & {$[0.198]$} & [0.0118] & [0.9015] & [0.4939] & [0.6445] & {$[0.0624]$} & 0.0207 \\
\hline BP Statistic & 400.3 & 90.45 & 4.02 & 1.92 & 97.5 & 324.55 & 38.31 & 0.07 & 46.18 & $(2.03)$ \\
\hline p-value & {$[0.001]$} & {$[.0001]$} & {$[0.0550]$} & [0.167] & {$[.0001]$} & {$[.0001]$} & {$[.0001]$} & [0.7939] & {$[.0001]$} & $(0.976)$ \\
\hline Model & $\mathrm{FE}$ & $\mathrm{FE}$ & $\mathrm{RE}$ & $\mathrm{RE}$ & $\mathrm{RE}$ & $\mathrm{RE}$ & $\mathrm{RE}$ & $\mathrm{FE}$ & $\mathrm{RE}$ & $\mathrm{FE}$ \\
\hline
\end{tabular}

Note: Figures in the parentheses indicate $t$ values and figures in square brackets indicate probability values. RE and FE represent the estimates obtained from random effect and fixed effect models respectively. "HM" indicates Hausman test statistic and "BP" indicates Breusch Pagan test statistic.

competition proxy affects MFIs outcome measures such as outreach, loan repayment, performance and profitability. The estimated univariate results are reported in Table 3. Before analyzing the univariate results, it is worth theorizing that increasing competition in a microfinance lending market space would be characterized by decreasing LI and vice versa. While analyzing the effect of competition on outreach, it is observed that LI is inversely associated with the "nab" and "albpb" of MFIs. That means, increasing competition among MFIs significantly increases their active borrower and loan size base and vice versa. This could be due to the unsaturated rural microfinance market with higher number of unbanked population. To capture this unsaturated market, MFIs are perhaps luring the customers with diverse promotional plans, products and benefits, extending high value loans and creating better socio economic awareness among unbanked population. Our results here don't support the findings of Assefa, et al. [3]. The loan repayment proxies "par30" and "par 90" are negatively affected by the competition proxy LI at $5 \%$ level of significance. That means competition deteriorates the repayment performance and rising default rates of the loan portfolio (Table 3).

While examining the univariate results associated with the effect of competition on MFI efficiency it reveals that both "oer" and cpb are positively affected by competition. But the level of significance associated with the loading proxies suggests that the positive effect of competition is strongly felt on "oer" compared to "cpb", which technically suggests that competition has very marginal effect on "cpb". However, the effect of competition on MFI profitability measured via "oss", "pm", "roa", and "roe" are adversely affected at an accepted level of significance. The loadings and the level of significance statistics for all the four performance proxies suggest that competition has a strong damaging effect on "pm" 
and a weak damaging effect on "roa" (Table 3).

Thus, the overall univariate result is mixed, where 1) competition has a direct and significant bearing on MFIs outreach, 2) competition deteriorates MFIs the repayment performance and rising default rates, 3) MFIs efficiency improves as competition exacerbates and 4) competition registers positive influence on MFIs financial performance.

Multivariate Analysis: Following microfinance literature [3] [28] [29], we include some of the important MFI and macro specific control variables along with our interest variables in the full modelling framework. Out of the six MFI specific variables plugged into the full models, competition (LI) a scale variable and state regulatory intervention (regulate) a dummy variable (after regulatory intervention is 1 and 0 otherwise) are our interest variables. Rest of the four MFI specific variables are control variables and out of which three are dummy variables such as "scale" which represents the scale of MFI operation ( 1 is large scale MFI and 0 otherwise); "region", which represents the regional diversities (1 is MFI operates in the southern states of India and 0 otherwise); "state intervention" ( 1 is after MFI regulation and 0 before regulation). The log of total asset is also used as a MFI specific factor representing size of the MFI. While among the macro variables, we deploy three major state level macro specific variables such as real yield, credit deposit ratio and per capita state gross domestic product for the respective states. The estimates of the full model are presented in Table 4.

\subsection{Effect of Competition on MFI Outcomes}

While investigating the effect of competition on MFI outreach the results suggest that competition significantly promotes MFI's active borrower and loan size. The result here partially does not lend support to the earlier literature [3], who contend that intense competition negatively affects wider outreach in terms of number of active borrowers and share of women borrowers. Thus, the empirical results reject both the null hypotheses under H1.1, which affirm that competition rather promotes the MFIs outreach (Table 4). That means, competition among MFIs significantly promotes their active borrower and loan size base. The positive effect of competition on MFI outreach in Indian could be due to the dependence of large unbanked rural and tribal population on informal finance and more responsible lending owing to appropriate regulation. Further in such unbanked and unsaturated informal financial market, the active promotional lending activities of the MFIs could have also widen the outreach and lending relatively larger loans to their clients so as to reap higher interest income. However, this study is not intending to prove whether compared to the client base growth, the loan book growth is much higher, indicating more money is given to the same client, which is a risky situation. This may be examined in a further study.

The results in the previous section reveal that MFIs are extending higher amount of loans to their customers over the period and enlarging their borrowing base. No doubt the loans are MFIs' largest assets and also the largest source 
Table 4. Multivariate results of the effect of competition, regulation and other control variables on MFI outcomes.

\begin{tabular}{|c|c|c|c|c|c|c|c|c|c|c|}
\hline \multirow{2}{*}{ Descriptions } & \multicolumn{2}{|c|}{ Outreach } & \multicolumn{2}{|c|}{ Loan Repayment } & \multicolumn{2}{|c|}{ Efficiency } & \multicolumn{4}{|c|}{ Profitability } \\
\hline & $\mathrm{Nab}$ & Albpb & par 30 & Par 90 & Oer & $\mathrm{cpb}$ & oss & $\mathrm{pm}$ & roa & roe \\
\hline \multirow[t]{2}{*}{ Intercept } & $1.159^{* *}$ & $3.434^{* * *}$ & $0.414^{* *}$ & 0.336 & $0.497^{\star * *}$ & 1.283 & 0.245 & 0.680 & 0.001 & -0.032 \\
\hline & $(-2.07)$ & $(4.69)$ & $(1.97)$ & $(0.096)$ & $(5.78)$ & 6.06 & $(0.76)$ & $(0.930)$ & $(0.031)$ & $(-1.02)$ \\
\hline \multirow[t]{2}{*}{ LI } & $-0.037^{\star}$ & $-0.3263^{*}$ & $-0.132^{\star}$ & $-0.094^{\star}$ & $-0.144^{\star * \star}$ & -0.068 & $0.292^{\star * *}$ & $0.374^{\star *}$ & $0.016^{* *}$ & $0.014^{*}$ \\
\hline & $(-1.69)$ & $(-1.76)$ & $(-1.901)$ & $(-1.84)$ & $(-5.56)$ & -1.13 & $(2.84)$ & $(2.030)$ & $(2.051)$ & $(1.83)$ \\
\hline \multirow[t]{2}{*}{ Regulate } & $0.142^{\star *}$ & $-0.285^{\star \star}$ & $-0.058^{\star}$ & $-0.069^{\star}$ & 0.007 & $-0.047^{\star}$ & 0.009 & -0.004 & 0.004 & $-0.014^{\star * *}$ \\
\hline & $(2.1)$ & $(-1.96)$ & $(-1.67)$ & $(-1.71)$ & $(0.63)$ & -1.81 & $(0.24)$ & $(-0.040)$ & $(0.82)$ & $(-3.67)$ \\
\hline \multirow[t]{2}{*}{ Scale } & $0.274^{\star}$ & 0.151 & 0.045 & 0.039 & 0.018 & -0.045 & -0.062 & 0.015 & $-0.014^{\star *}$ & -0.004 \\
\hline & $(1.91)$ & $(1.23)$ & $(1.23)$ & $(0.255)$ & $(1.08)$ & -0.84 & $(-0.98)$ & $(0.280)$ & $(-1.99)$ & $(-0.74)$ \\
\hline \multirow[t]{2}{*}{ Dregion } & $-0.368^{\star}$ & $-0.401^{\star *}$ & -0.052 & -0.047 & 0.014 & $0.161^{* * *}$ & -0.069 & 0.024 & -0.003 & 0.008 \\
\hline & $(-1.93)$ & $(-2.24)$ & $(-0.99)$ & $(-0.94)$ & $(0.60)$ & $(2.35)$ & $(-0.80)$ & $(0.170)$ & $(-0.27)$ & $(0.97)$ \\
\hline \multirow[t]{2}{*}{ Lta } & $1.76^{* * *}$ & $0.526^{\star * \star}$ & -0.023 & -0.018 & $-0.054^{* * *}$ & $0.105^{* * *}$ & $0.175^{\star \star *}$ & 0.045 & 0.003 & $0.006^{*}$ \\
\hline & $(27.58)$ & $(6.63)$ & $(-1.01)$ & $(-0.80)$ & $(-5.50)$ & $(4.3)$ & $(4.77)$ & $(0.630)$ & $(0.75)$ & $(1.76)$ \\
\hline \multirow[t]{2}{*}{ Mfireg } & 0.008 & 0.066 & $0.069^{* * *}$ & $0.058^{\star \star}$ & -0.006 & -0.008 & -0.051 & $-0.191^{\star * *}$ & $-0.012^{\star \star \star}$ & $-0.013^{\star * *}$ \\
\hline & $(0.15)$ & $(0.71)$ & $(2.70)$ & $(2.34)$ & $(-0.68)$ & $(-0.37)$ & $(-1.47)$ & $(-2.270)$ & $(-2.93)$ & $(-3.21)$ \\
\hline \multirow[t]{2}{*}{ Ryield } & -0.288 & $-1.252^{\star *}$ & -0.434 & $-0.328^{\star *}$ & $0.344^{\star * *}$ & -0.195 & $1.952^{* * *}$ & 0.0565 & -0.003 & 0.027 \\
\hline & $(-0.82)$ & $(-2.16)$ & $(-2.66)$ & $(-2.08)$ & $(5.52)$ & $(-1.43)$ & $(8.44)$ & $(0.180)$ & $(-0.11)$ & $(1.09)$ \\
\hline \multirow[t]{2}{*}{$\mathrm{Cdr}$} & 0.004 & -0.004 & 0.001 & 0.001 & -0.0002 & 0.001 & $-0.003^{* *}$ & 0.0147 & 0.0002 & 0.002 \\
\hline & $(0.08)$ & $(-1.59)$ & $(1.22)$ & $(0.82)$ & $(-0.46)$ & $(1.04)$ & $(-2.29)$ & $(1.01)$ & $(1.01)$ & $(0.18)$ \\
\hline \multirow[t]{2}{*}{ Dgsdp } & 0.003 & $0.013^{\star \star}$ & 0.001 & 0.001 & $0.002^{*}$ & 0.001 & -0.0004 & $0.029^{*}$ & 0.0023 & 0.0002 \\
\hline & $(0.06)$ & (1.99) & $(0.23)$ & $(0.09)$ & $(1.70)$ & $(0.25)$ & $(-0.13)$ & $(1.675)$ & $(0.62)$ & $(0.59)$ \\
\hline R Square & 0.7786 & 0.3262 & 0.0934 & 0.066 & 0.289 & 0.1478 & 0.329 & 0.033 & 0.109 & 0.126 \\
\hline HM Statistic & 12.53 & 11.54 & 28.51 & 28.87 & 12.99 & 3.85 & 36.79 & 24.76 & 8.29 & 4.70 \\
\hline$P$ values & {$[0.252]$} & $\begin{array}{l}{[0.241]} \\
0.2407 \\
0.2407\end{array}$ & {$[0.001]$} & [0.001] & {$[0.1630]$} & [0.921] & {$[.0001]$} & {$[0.0032]$} & {$[0.5056]$} & [0.8595] \\
\hline BP Statistic & 327.02 & 4.08 & 4.15 & 1.65 & 1.35 & 299.57 & 55.03 & 0.39 & 55.56 & 10.44 \\
\hline $\mathrm{P}$ values & {$[0.0001]$} & [0.043] & [0.0417] & [0.199] & [0.165] & {$[0.0001]$} & {$[0.0001]$} & [0.5331] & {$[0.0001]$} & [0.0012] \\
\hline Model & $\mathrm{FE}$ & $\mathrm{FE}$ & $\mathrm{RE}$ & RE & $\mathrm{RE}$ & $\mathrm{RE}$ & $\mathrm{RE}$ & $\mathrm{FE}$ & $\mathrm{RE}$ & $\mathrm{FE}$ \\
\hline
\end{tabular}

Note: Figures in the parentheses indicate t values and figures in square brackets indicate probability values. "HM" indicates Hausman test statistic and "BP" indicates Breusch Pagan test statistic.

of risk resides in their loan portfolio. Competition among the MFIs might have affected the portfolio quality and financial stability of MFIs. Thus, it is worth monitoring that the credit quality of the MFIs loan portfolio remains steady, and hasn't shown significant uptick in delinquencies. Against this backdrop, we intend to investigate the effect of competition on MFI loan repayment through two 
proxies i.e. "par 30" and "par 90" in the presence of selected MFI and macro specific variables described in the earlier section. The estimated results are reported in column 3 and 4 of Table 4.

The results here affirm that MFI loan portfolios don't remain steady, and has shown significant uptick in delinquencies. The coefficients attached to both delinquency indicators are statistically significant at $10 \%$ level. The study reports that there is decline in loan repayment performance and worsening of loan portfolio quality as a result of intense competition among MFIs. This result supports both the specific hypotheses under H1.2 that competition erodes the MFI portfolio quality both for 30 days and 90 days respectively. Thus it is concluded that there is a significant rise in loan delinquency and default rates due to competition. The results here support the study [3] conducted in the world market context.

Indian MFIs are being criticized for their shift in the objective of serving the poor to becoming profit-making institutions. Serving the poor is a relatively costlier issue which may act as deterrent for efficient business operation and management. The competition in the MFIs space might have a bearing on MFIs financial efficiency. The MFIs efficiency is measured via two proxies, i.e., operating expenses ratio (oer) and the cost per borrower (cpb). Following the literature [3], we hypothesize that higher the competition among MFIs, lower is the level of efficiency. The estimated results are reported in column 5 and 6 of the Table 4.

The estimated result reveals that "oer" and "cpb" are negatively related with LI. However, it is only the "oer" observed to be significant at $1 \%$ level of significance, which suggests that competition positively affects "oer". MFIs have two main cost components finance costs (fees and interest on borrowings) and operating costs (admin and overhead costs and employee costs). The result here is mixed and we reject our alternative hypothesis (H1.3.1) which concludes that competition enhances MFIs operating efficiency. But the result did not lend any support to hypothesis (H1.3.2). That means the competitive pressure help MFIs to reduce cost components but they have been successful in reducing operating cost but not the financing cost.

Using a multivariate panel framework, the effect of competition on MFIs profitability is examined in the presence of MFI specific and state macro specific control variables and the results are reported in column 7, 8, 9 and 10 of the Table 4. The results reveal that competition has a negative bearing on the MFIs profitability. It is the "oss", which is far deeper impacted by the competition followed by "pm", "roa" and "roe". These findings lend support for our hypothesis with regard to MFIs financial performance (H1.4.1, H1.4.2, H1.4.3 and H1.4.4), which affirm that competition erodes the MFIs operating self-sufficiency, operating profit and return on asset. That means all the measures of financial performance are directly related with LI suggesting rising competition (inverse of the index) declines profits of MFIs. 


\subsection{Effect of Regulatory Intervention on MFI Outcome}

The importance of MFIs in fulfilling the goals of financial inclusion in India can't be undermined. It is thus essential to develop a legal and financial framework of rules and regulations which would govern MFIs. Following the aftermath of the Andhra Pradesh (AP) microfinance issue and AP state MFI regulations and the subsequent rise of the microfinance industry nevertheless, various prudential and non-prudential norms were evolved by the regulatory bodies in the country in order to effectively regulate MFIs. Still there are multiple MFIs regulatory authorities and at the apex the RBI's regulation of 2011 plays an important role. However, this section makes an attempt to examine how regulatory intervention either by state or any other authority have affected the MFIs outreach, loan repayment, efficiency and profitability outcomes. The method and variables associated with these outcome measures are explained in-depth in the earlier section and we have deliberately avoided such a discussion. However, an attempt is made here to model the effect of regulation on MFI outreach, loan repayment, and efficiency and profitability outcomes in a multivariate framework in the presence of MFI specific and macro specific variables. The results are also reported both in Table 4.

While investigating the effect of regulatory intervention on MFI outreach, we find inconclusive results, where regulatory intervention promotes the "nab" and erodes the "albpb". The empirical results here reject H2.1.1 and accept H2.1.2 and affirm that regulatory intervention rather promotes the MFIs active borrowers base, and erodes MFIs loan size at 5\% level of significance (Table 4). Our conjecture is seen to have been partially true that the regulatory intervention has promoted wider outreach (measured by "nab") and it has eroded the depth of outreach (measured by "albpb") in the Indian microfinance market. We may perceive that number of active borrowers' base has gone up could have been due to more responsible lending owing to appropriate regulation.

State regulatory intervention might have affected the portfolio quality and financial stability of MFIs. While examining the effect of regulation on MFI loan repayment via "par30" and "par90" in a full modeling framework, it is observed that regulation has a significantly negative effect on loan repayment proxies. The results here confirm two specific hypotheses under H2.2 and thus confirm that regulatory intervention has eroded MFI loan quality.

While examining the effect of state regulation on MFIs financial efficiency, the results are found to be inconclusive, which is reported in the column 5 and 6 of Table 4 . The results here suggest that state regulation have a statistically significant negative bearing on "cpb" but not on "oer". It can be inferred from the results that the regulation has partially helped improving MFIs efficiency in terms of cost per borrower. Thus, the result here only partially confirms one of our efficiency hypotheses H2.3.2.

The effect of state intervention on MFIs financial performances are examined in the presence of MFI specific and state macro specific control variables and the 
results are reported in column 7, 8, 9 and 10 of the Table 4 . The results reveal that the state intervention has a significant negative bearing only on the MFIs "roe" but not on "oss", "pm" and "roa". This finding partially confirms one of the financial performance hypotheses that state regulation erodes the MFIs return on equity (H2.4.4). However, at a broader level, the results are observed to be inconclusive due to divergent signs across the coefficients attached to the MFIs financial performance indicators.

\section{Conclusions and Implications}

The effect of competition and regulation on MFI outcomes has not been much studied systematically in the Indian microfinance space which we fill with the findings of our study. Using the MIX Market dataset in a panel model framework of 60 MFIs for 5 years, the empirical results by large point towards mixed effects of increased competition and state regulation on MFIs outcomes are detailed hereunder.

The competition strengthens the outreach and deteriorates loan portfolio quality of MFIs. It could be inferred from the findings that to thrive in the competition, MFIs in India are engaged in strategizing operational plans to enhance their borrower base and disburse larger amount loan to their clients. A the same time, it is observed that there is a significant uptick in delinquencies which in turn deteriorates loan portfolio quality in the face of intense competition among MFIs. Rising level of such non-performing loans and defaults, imply either a systemic or an idiosyncratic problem in the Indian MFI Industry. The multiple borrowings, lack of proper need-assessment for lending, lack of loan monitoring system, lack of client education and motivation, unhealthy competition among the MFIs, political decision, government policy and regulatory intervention might have a bearing on the poor MFI loan portfolio quality. The study also points out that in the face of competition, MFIs are better managing the operating expenses but not the cost of borrowings. It could be due to the fact that the operational cost is idiosyncratic in nature and thus is better managed and the cost of borrowings is externally determined and thus just can't be managed by MFIs. The study also affirms that competition has a negative bearing on the MFIs profitability. It could be attributed to the multiple lending to the same borrowers by different MFIs, who are in turn unable to invest and repay on time. This practice might have benefited the borrowers in terms of availability of more funds but it has adversely affected the loan portfolio quality in turn deterioration of MFI profitability.

The study concludes that the effects of regulation on MFIs outcomes are inconclusive except the findings on MFI loan defaults and portfolio quality. Regulatory intervention has promoted the active borrowers base on the one hand and on the other hand, it has eroded the average loan size of MFIs in India. But, how can we justify that regulation has partially a negative bearing on the MFIs outreach (eroded albpb) and efficiency (cpb). The diverse microfinance write-ups 
suggest that the regulations on the MFIs have restricted their operation and downsized their loan portfolio. Regulation has also encouraged the lenders to deepen their outreach in limited area and expand to new areas which are inaccessible and unreachable. The mandatory registration of borrower's records in the Credit Information Bureau of India Limited (CIBIL) might have helped MFIs to improve their portfolio quality and efficiency to operate in specific area. However, this result requires to be verified further in a broader larger panel context. Further we conclude that regulatory intervention has adverse effects on loan repayments and portfolio quality, which has contributed towards the MFIs financial instability in India. Further, how can it be justified that regulation has a negative bearing on loan repayment? From the Indian microfinance experience, it could be stated that the regulations restricted fund flow for the borrowers as well as the lenders. In expectation of future non-availability of loan funds, the borrowers stopped their repayment, which affected the loan repayment rate for the MFIs. But, the post-regulation period streamlined lending process for the MFIs and created opportunity to seek avenues of further funding. This goes towards ensuring sustainability for the MFIs. Understanding the effect of state regulation on MFIs financial efficiency, the results are found to be inconclusive, where regulation has partially helped improve MFIs efficiency via reduction in cost per borrowings. Finally the effect of state regulation on MFIs financial performance are observed to be inconclusive, wherein market linked financial performance measure is adversely affected than the books of accounts based financial measures remained in sensitive.

Thus, the study, on the one hand concludes that competition strengthens the outreach; induce to operating efficiency, deteriorates the loan portfolio quality and adversely affects the MFIs profitability. On the other, the regulatory intervention creates some accommodative space for the MFI borrowers, improves MFIs efficiency partially and dampens loan repayments and portfolio quality and profitability via "roe" in India.

This study enhances our understanding on the effect of competition and regulation on MFIs outreach, loan repayment and portfolio quality, efficiency and financial performance in India. This study contributes towards filling gap in the literature by extending the analysis of the effect of competition and regulation on MFI outcomes to a cross-section of states in India in a panel data framework. Our results have also implications on MFIs, fund provider, regulator, government and policy research practitioners. The findings may influence the MFIs to redesign their products and services to promote outreach, efficiency and profitability and find the way out for information sharing among them to improve portfolio quality and reduce loan defaults in the face of intense competition. Donors and fund providers to MFI may re-examine the state of efficiency and performance of MFIs individually before lending or donating such resources for the greater good of the society. The results may have implication for regulators, competition commission and policy makers in India where they should monitor 
and ensure the desired effect of competition and regulation on MFIs outcomes. However, there is a need for verifying these results in a broader panel framework before using this study results for the regulation and public policy provisioning. The study is not free from limitations, as we have analyzed only a restricted panel data set due to non-availability of data both for cross section and time series. However, our results would no doubt ignite further discourse on understanding the effect of competition and regulation on MFIs outcome in general and India in particular.

\section{References}

[1] Ghosh, S. and Van Tassel, E. (2011) Microfinance and Competition for External Funding. Economics Letters, 112, 168-170. https://doi.org/10.1016/j.econlet.2011.03.037

[2] Rhyne, E. and Otero, M. (2006) The Changing Face of Microfinance: Closing the Quality Gap. Micro Banking Bulletin, 13, 1-7.

[3] Assefa, E., Hermes, N. and Meesters, A. (2013) Competition and the Performance of Microfinance Institutions. Applied Financial Economics, 23, 767-782. https://doi.org/10.1080/09603107.2012.754541

[4] Vogelgesang, U. (2003) Microfinance in Times of Crisis: The Effects of Competition, Rising Indebtedness, and Economic Crisis on Repayment Behavior. World Development, 31, 2085-2114. https://doi.org/10.1016/j.worlddev.2003.09.004

[5] Kar, A.K. and Swain, R.B. (2014) Interest Rates and Financial Performance of Microfinance Institutions: Recent Global Evidence. The European Journal of Development Research, 26, 87-106. https://doi.org/10.1057/ejdr.2013.33

[6] Demsetz, H. (1974) Toward a Theory of Property Rights. In: Classic Papers in Natural Resource Economics, Palgrave, Macmillan UK, 163-177. https://doi.org/10.1057/9780230523210_9

[7] Earle, J., Estrin, S. and Leshchenko, L. (1996) Ownership Structures, Patterns of Control, and Enterprise Behavior in Russia. Enterprise Restructuring and Economic Policy in Russia, 205-252.

[8] Navajas, S., Conning, J. and Gonzalez-Vega, C. (2003) Lending Technologies, Competition and Consolidation in the Market for Microfinance in Bolivia. Journal of International Development, 15, 747-770. https://doi.org/10.1002/jid.1024

[9] McIntosh, C. and Wydick, B. (2005) Competition and Microfinance. Journal of Development Economics, 78, 271-298. https://doi.org/10.1016/j.jdeveco.2004.11.008

[10] Marquez, R. (2002) Competition, Adverse Selection, and Information Dispersion in the Banking Industry. Review of Financial Studies, 15, 901-926. https://doi.org/10.1093/rfs/15.3.901

[11] Berger, A.N., Dick, A.A., Goldberg, L.G. and White, L.J. (2007) Competition from Large, Multimarket Firms and the Performance of Small, Single-Market Firms: Evidence from the Banking Industry. Journal of Money, Credit and Banking, 39, 331-368. https://doi.org/10.1111/j.0022-2879.2007.00028.x

[12] Cull, R. and Morduch, J. (2007) Financial Performance and Outreach: A Global Analysis of Leading Microbanks. The Economic Journal, 117, 107-133. https://doi.org/10.1111/j.1468-0297.2007.02017.x

[13] Gonzalez, A. (2010) Is Microfinance Growing Too Fast? MIX Data Brief No. 5.

[14] Claessens, S. (2009) Competition in the Financial Sector: Overview of Competition 
Policies. The World Bank Research Observer, 24, 83-118.

https://doi.org/10.1093/wbro/lkp004

[15] Kai, H. (2009) Competition and Wide Outreach of Microfinance Institutions. Munich.

[16] Meyer, R.L. (2010) Microfinance, Poverty Alleviation and Improving Food Security: Implications for India. Food Security and Environmental Quality in the Developing World, 347.

[17] Tabak, B.M., Fazio, D.M. and Cajueiro, D.O. (2012) The Relationship between Banking Market Competition and Risk-Taking: Do Size and Capitalization Matter? Journal of Banking \& Finance, 36, 3366-3381. https://doi.org/10.1016/j.jbankfin.2012.07.022

[18] Franks, J.R. (2000) Macroeconomic Stabilization and the Microentrepreneur. Journal of Microfinance, 2, 69-91.

[19] Cull, R., Demirgüç-Kunt, A. and Morduch, J. (2011) Does Regulatory Supervision Curtail Microfinance Profitability and Outreach? World Development, 39, 949-965. https://doi.org/10.1016/j.worlddev.2009.10.016

[20] Christen, R.P., Lyman, T.R. and Rosenberg, R. (2003) Microfinance Consensus Guidelines: Guiding Principles on Regulation and Supervision of Microfinance. CGAP, The World Bank Group, Washington DC.

[21] Ndambu, J. (2011) Does Regulation Increase Microfinance Performance in Sub-Saharan Africa? Frankfurt School of Finance \& Management, Frankfurt.

[22] Wanjiru, M.C. (2012) Effect of Financial Regulation on Financial Performance of Deposit-Taking Microfinance Institutions in Kenya. Unpublished MBA Project, University of Nairobi, Nairobi.

[23] Yu, V., Damji, R., Vora, V. and Anand, L. (2014) Regulation on Microfinance: Effect upon Profitability and Loan Diversity. UChicago Undergraduate Business Journal, 1-20.

[24] Hartarska, V. and Nadolnyak, D. (2007) Do Regulated Microfinance Institutions Achieve Better Sustainability and Outreach? Cross-Country Evidence. Applied Economics, 39, 1207-1222. https://doi.org/10.1080/00036840500461840

[25] De Guevara, J.F. and Maudos, J. (2004) Measuring Welfare Loss of Market Power: An Application to European Banks. Applied Economics Letters, 11, 833-836. https://doi.org/10.1080/1350485042000263908

[26] Hermes, N., Lensink, R. and Meesters, A. (2009) Financial Development and the Efficiency of Microfinance Institutions. https://doi.org/10.2139/ssrn.1396202

[27] Yaron, J. (1992) Assessing Development Finance Institutions: A Public Interest Analysis. World Bank Policy Research Working Paper, Paper No. 174, Washington DC.

[28] Schreiner, M. (2001) Informal Finance and the Design of Microfinance. Development in Practice, 637-640.

[29] Olivares-Polanco, F. (2005) Commercializing Microfinance and Deepening Outreach? Empirical Evidence from Latin America. ESR Review, 7, 47.

[30] Ahlin, C., Lin, J. and Maio, M. (2011) Where Does Microfinance Flourish? Microfinance Institution Performance in Macroeconomic Context. Journal of Development Economics, 95, 105-120. https://doi.org/10.1016/j.jdeveco.2010.04.004

[31] Cull, R., Asli Demirgüç-Kunt, A. and Morduch, J. (2009) Microfinance Meets the Market. Journal of Economic Perspectives, 23, 167-192.

https://doi.org/10.1257/jep.23.1.167 